\title{
ANALISIS KESALAHAN DALAM MENYELESAIKAN SOAL BARISAN DAN DERET BERDASARKAN KATEGORI WATSON
}

\author{
Oktavianingsih $\mathbf{C}^{1}$, Maharani $\mathrm{A}^{2}$, Wahyuni $\mathrm{I}^{3}$ \\ 1,2,3 Program Pendidikan Matematika, Universitas Swadaya Gunung Jati Cirebon, Jl. Dr. Setiabudi No. 229, \\ Bandung, 40154, Indonesia, cucuoktaviamath@gmail.com
}

Diterima 03 Juli 2019, disetujui 30 September 2019, diterbitkan 31 Oktober 2019

Pengutipan: Oktavianingsih, C., Maharsni, A., \& Wahyuni, I. (2019). Analisis Kesalahan dalam Menyelesaikan Soal Barisan dan Deret Berdasarkan Kategori Watson. Gema Wiralodra, Vol 10, No 2, Hal 253-262, Oktober 2019

\begin{abstract}
ABSTRAK
Kemampuan siswa dalam pembelajaran matematika masih kurang dari pada pembelajaran yang lainnya. Banyak siswa yang sering melakukan kesalahan dalam menyelesaikan soal berkaitan dengan materi barisan dan deret. Kesalahan dalam menyelesaikan soal dapat diartikan sebagai penyimpangan dari sesuatu yang benar. Tujuan dari penelitian ini untuk (i) mengetahui jenis kesalahan dalam menyelesaikan soal barisan dan deret berdasarkan kategori Watson, (ii) untuk mengetahui presentase setiap jenis kesalahan dalam menyelesaikan soal barisan dan deret berdasarkan kategori Watson. Jenis penelitian ini adalah penelitian deskriptif kualitatif. Penelitian ini dilakukan dengan memberikan tes berbentuk uraian sebanyak empat soal, dari jawaban siswa akan dianalisis dimana letak kesalahan siswa agar pembelajaran berikutnya dapat diperbaiki. Hasil jawaban siswa dianalisis dengan menggunakan kategori Watson. Hasil penelitian yang didapat adalah kesalahan yang sering dilakukan oleh siswa berdasarkan kategori Watson yaitu Kategori prosedur tidak tepat, dan pada kategori prosedur tidak tepat didapat presentase kesalahan keseluruhan sebesar 34,06\%.
\end{abstract}

Kata Kunci: Analisis Kesalahan, Barisan dan Deret, Kategori Watson

\begin{abstract}
The ability of students in learning mathematics is still less than in other learning. Many students often make mistakes in solving problems related to row and series material. Errors in solving problems can be interpreted as deviations from something true. The purpose of this study is to (i) find out the types of errors in solving row and series problems based on the Watson category, (ii) to determine the percentage of each type of error in solving row and series problems based on the Watson category. This type of research is a qualitative descriptive study. This research was conducted by giving a test in the form of a description of as many as four questions, from which students' answers will be analyzed in which the location of student errors so that subsequent learning can be corrected. The results of student answers were analyzed using the Watson category. The results obtained are errors that are often made by students based on the Watson category, namely the improper procedure category, and the inappropriate procedure category obtained an overall error percentage of $34.06 \%$.
\end{abstract}

Keywords: Error Analysis, Sequence, and Series, Watson Category

\section{PENDAHULUAN}

Matematika adalah ilmu pasti yang selama ini dibutuhkan untuk mempelajari ilmu lainnya. Pembelajaran di sekolah siswa akan diberikan banyak mata pelajaran dan salah satunya adalah pelajaran matematika. Salah satu contoh dari penggunaan matematika adalah saat manusia melakukan transaksi jual beli mereka harus bisa menghitung jumlah belanjaan 
yang dibeli maupun menghitung harga jual suatu barang agar tidak rugi, dan dalam mempelajari materi lain juga membutuhkan ilmu matematika contohnya seperti belajar fisika, kimia, dan masih banyak lainnya. Oleh karena itu, sangat penting untuk anak-anak dibekali ilmu matematika sedini mungkin dari sekolah taman kanak-kanak sampai jenjang SMA bahkan sampai perguruan tinggi. Seperti yang dikemukakan oleh Ratnasari dkk (2017: 95) pelajaran matematika diajarkan mulai dari jenjang pendidikan dasar yang berfungsi untuk membentuk pola pikir anak, sedangkan menurut Maharani (2014: 73) mata pelajaran matematika mampu diterapkan dalam program keahlian para siswa.

Di Indonesia kurikulum pendidikan yang digunakan sering berubah, hal tersebut dilakukan agar dapat memperbaiki pendidikan di Indonesia dari tahun ke tahunnya. Berdasarkan kurikulum 2013, satu diantara materi yang dipelajari oleh siswa kelas XI semester ganjil adalah materi barisan dan deret, di Sekolah manapun pasti akan mempelajari materi barisan dan deret. Barisan dan deret berhubungan dengan kehidupan manusia, sehingga diharapkan peserta didik dapat lebih mudah dalam mempelajarinya. Siswa akan mempelajari dua bahasan tentang barisan dan deret yaitu aritmetika dan geometri. Menurut Manullang (2017: 180) melalui pembelajaran materi barisan dan deret, diharapkan siswa mampu berpikir tingkat tinggi untuk menyelesaikan suatu permasalahan.

Rendahnya kemampuan matematik siswa daat dilihat dari penguasaan materi Yunita, Y., Sunardi, S., \& Dafik, D. (2013) dan biasanya guru memberikan suatu permasalahan berupa tes, baik itu tes tertulis maupun tes lisan kepada siswa. Masalah merupakan suatu permasalahan yang tidak mempunyai jalan keluar untuk menjawabnya. Tes uraian (essay) cocok digunakan dalam pembelajaran matematika, karena dari jawaban tes essay dapat dilihat dimana letak kesalahan siswa, dan dari jawaban tes tersebut dapat dianalisis dimana letak kesalahan siswa dalam menyelesaikan suatu permasalahan yang diberikan, sehingga guru dapat melakukan tindakan memperbaiki dipembelajaran berikutnya. Analisis kesalahan yang dilakukan oleh siswa penting dilakukan karena dapat menjadi pertimbangan perbaikan dalam pembelajaran berikutnya misalnya dalam penggunaan media ajar.

Banyak penelitian-penelitian terkait dengan analisis kesalahan berdasarkan kategori Watson seperti (1) Munawaroh, Rohaeti \& Aripin (2018) melakukan analisis kesalahan siswa dalam menyelesaikan soal komunikasi matematis siswa SMP. (2) Susilawati \& Febrian (2016) melakukan analisis kesalahan siswa dalam menyelesaikan permasalahan peluang. (3) Hariyani, Aisyah \& Dinullah (2019) melakukan analisis kesalahan 
penyelesaian soal cerita. (4) Isran (2017) melakukan analisis kesalahan siswa dalam menyelesaikan tes kemampuan berpikir kritis materi fungsi eksponen. (5) Sudirman (2016) melakukan analisis terhadap kecenderungan kesalahan siswa dalam menyelesaikan masalah segitiga.

Berdasarkan hasil penelitian-penelitian sebelumnya memperlihatkan bahwa tidak ada yang menganalisis kesalahan siswa dalam menyelesaikan masalah barisan dan deret. Oleh karena itu, masalah dalam penelitian ini adalah (i) bagaimanakah jenis kesalahan yang dilakukan siswa dalam menyelesaikan soal barisan dan deret berdasarkan kategori Watson?, (ii) bagaimana persentase setiap jenis kesalahan dalam menyelesaikan soal barisan dan deret berdasarkan kategori Watson?, sedangkan tujuan dari penelitian ini adalah (i) mendeskripsikan jenis kesalahan dalam menyelesaikan soal barisan dan deret berdasarkan kategori Watson, (ii) mendeskripsikan persentase setiap jenis kesalahan dalam menyelesaikan soal barisan dan deret berdasarkan kategori Watson. Salah satu kategori yang dapat digunakan untuk menganalisis kesalahan-kesalahan siswa adalah kategori Watson karena kategori Watson sering ditemukan dalam kesalahan-kesalahan yang dilakukan oleh siswa dan lebih memudahkan dalam melacak dimana letak kesalahan yang sering dilakukan siswa. 8 kategori Watson terdiri dari: (1) data tidak tetap (id), (2) prosedur tidak tepat (ip), (3) data hilang (oc), (4) kesimpulan hilang (od), (5) konflik level respons (rlc), (6) manipulasi tidak langsung (um), (7) masalah hirarki keterampilan (shp), (8) kategori lainnya $(a o)$.

\section{METODOLOGI PENELITIAN}

Penelitian ini merupakan penelitian deskriptif kualitatif yang bertujuan untuk meneliti dimana letak kesalahan yang sering dilakukan oleh siswa saat menyelesaikan soal barisan dan deret. Subyek penelitian ini sebanyak 18 siswa tepatnya kelas XI IPS di salah satu sekolah di kota Cirebon, Indonesia. Metode pengumpulan data yang digunakan dalam penelitian ini adalah 1) metode tes yang digunakan untuk mengidentifikasi kesalahan siswa dalam menyelesaikan soal menurut kategori Watson, dan 2) metode wawancara dilakukan kepada siswa yang menjawab soal mengenai jawaban pada tes tertulis untuk mengetahui cara berfikir siswa. Menurut Patton tujuan dari wawancara adalah untuk mencari tahu apa yang ada dalam pikiran seseorang (Michalak, 2018). Analisis data kualitatif dilakukan dalam tiga tahap, yaitu: Reduksi data, Penyajian data, dan Penarikan kesimpulan (Hastari, 2018: 186). 


\section{HASIL DAN PEMBAHASAN}

Penelitian ini dilakukan pada siswa di Kelas XI IPS di salah satu sekolah di kota Cirebon pada tanggal 30 April - 24 Mei 2019. Berikut hasil analisis menurut kategori Watson.

\section{Soal Nomor 1}

Kesalahan siswa dalam menjawab soal Nomor 1 berdasarkan kategori Watson kemudian dianalisis dan dituangkan kedalam tabel 1:

Tabel 1. Hasil analisis soal Nomor 1

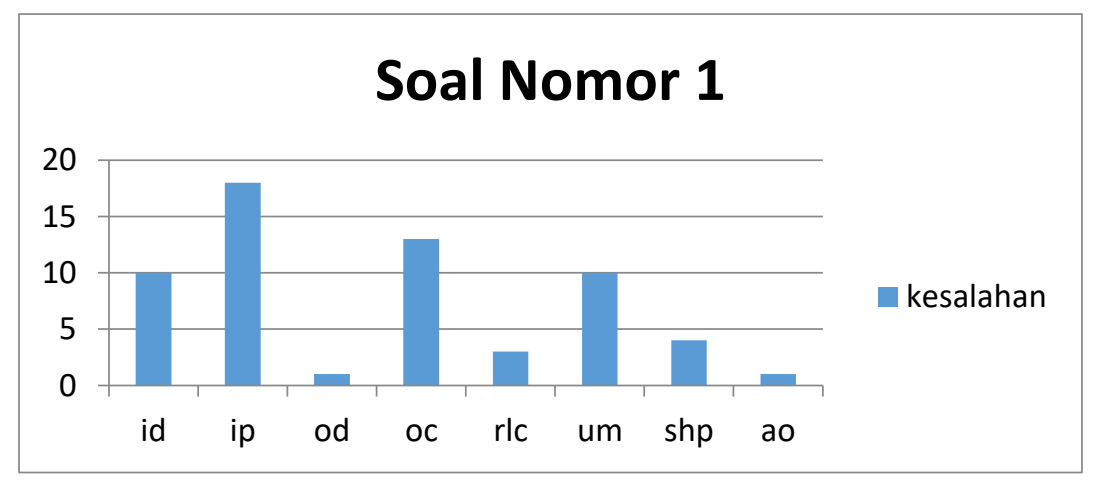

Analisis Soal:

Berdasarkan Tabel 1 didapatkan bahwa kategori kesalahan yang dilakukan siswa bervariasi. Terdapat 18 siswa yang masuk dalam kategori prosedur tidak tepat dan 13 siswa yang melakukan kesalahan pada kategori kesimpulan hilang, untuk kategori prosedur tidak tepat siswa masih salah dalam membedakan mana Ut dan Un. Dilihat dari jawaban, ada beberapa siswa yang masih salah dalam menggunakan rumus karena masih menggunakan rumus Un dalam menyelesaikan soal padahal pertanyaan yang diminta pada soal adalah suku keberapa suku tengahnya bukan suku keberapa suku ke-nnya. Karena siswa masih salah dalam menggunakan rumus maka terdapat beberapa siswa juga yang melakukan kesalahan pada kategori kesimpulan hilang yaitu dalam menyelesaikan soal siswa belum sampai pada tahap akhir yang diminta dalam soal karena saat awal menentukan rumus siswa sudah salah. Kategori selanjutnya adalah kategori manipulasi tidak langsung dan masalah hirarki keterampilan terdapat 10 siswa. Dalam kategori manipulasi tidak langsung, siswa menggunakan alasan yang tidak logis dalam menyelesaikan soal, sedangkan pada kategori hirarki keterampilan siswa masih salah dalam mengoperasikan penjumlahan dan perkalian, saat ditemukan operasi penjumlahan dan perkalian siswa masih belum paham mana yang harus dioperasikan terlebih dahulu yaitu pada operasi $6+3(36-1)$ beberapa 
siswa mengoperasikan terlebih dulu penjumlahan antara $6+3=9$ kemudian melanjutkan dengan mengoperasikan $(36-1)=35$ dan selanjutnya hasil dari keduanya dikalikan $9(35)=315$ seharusnya siswa terlebih dahulu mengoperasikan yang terdapat dalam kurung dan kemudian mendahulukan perkalian dan terakhir penjumlahan yaitu $6+$ $3(36-1)=6+3(35)=6+105=165$.

\section{Soal Nomor 2}

Kesalahan siswa dalam menjawab soal Nomor 1 berdasarkan kategori Watson kemudian dianalisis dan dituangkan kedalam tabel 2:

Tabel 2. Hasil analisis soal Nomor 2

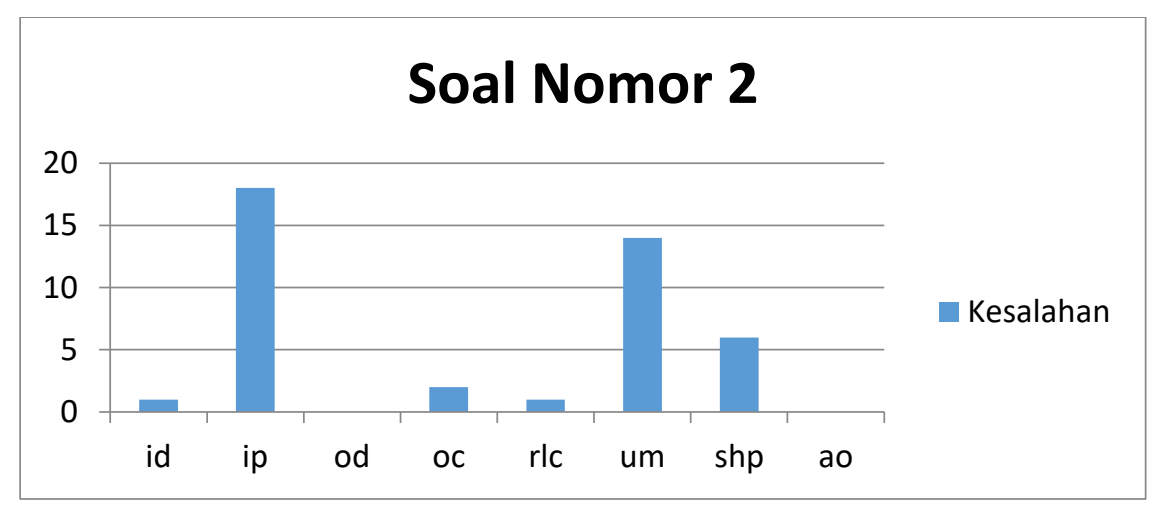

Analisis Soal:

Berdasarkan Tabel 2 terlihat sangat menonjol bahwa kesalahan kategori ip dilakukan semua siswa yaitu sebanyak 18 siswa, kesalahan tersebut dilakukan oleh siswa karena siswa kurang tepat dalam melakukan langkah-langkah penyelesaian. Beberapa siswa sudah tepat dalam menggunakan rumus yang harus dipakai tetapi prosedur dalam menyelesaikan soal tidak tepat dilakukan siswa, karena pada tahap mencari nilai suku pertama, siswa melakukan kesalahan pada tahap $a+15=11$ mereka menuliskan hasilnya yaitu $a=$ $15-11$ yang menghasilkan nilai $a=4$, ada juga yang menjawab $a=11-15$ hasilnya adalah $a=-4$, seharusnya siswa menjawab dengan cara $a+15=11$ dengan cara kedua ruas dikurangi dengan 15 untuk menghilangkan nilai 15 diruas kiri yaitu $a+15-15=$ $11-15$, menghasilkan $a=11-15$ menghasilkan nilai $a=-4$. Karena dari awal penyelesaian siswa sudah melakukan tahap yang tidak benar dan logis, maka yang terjadi siswa salah dalam mendapat nilai suku pertamanya dan menyebabkan kesimpulan yang didapatkan siswa juga menjadi salah.

\section{Soal Nomor 3}


Kesalahan siswa dalam menjawab soal Nomor 1 berdasarkan kategori Watson kemudian dianalisis dan dituangkan kedalam tabel 3:

Tabel 3. Hasil analisis soal Nomor 3

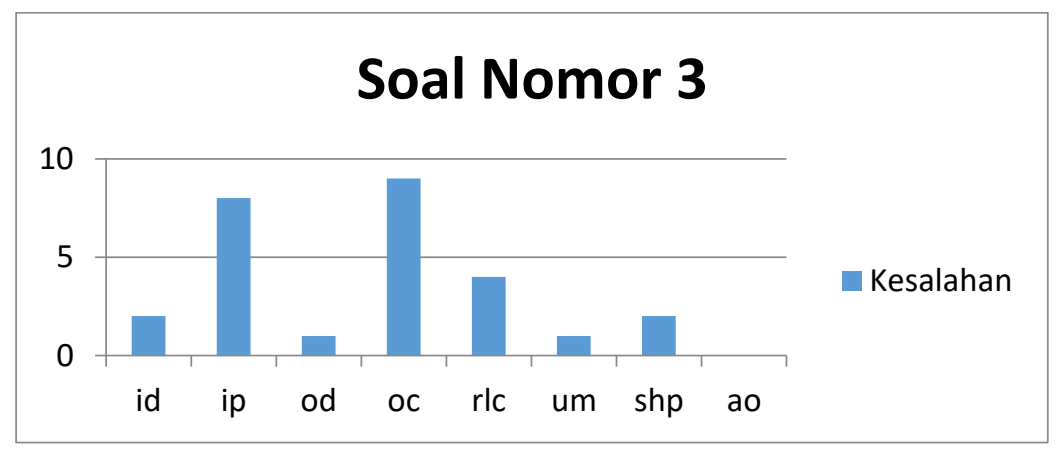

Analisis Soal:

Berdasarkan Tabel 3 terlihat bahwa kesalahan pengerjaan soal Nomor 3 yaitu kesalahan oc atau kesimpulan hilang dimana beberapa siswa masih salah dalam menggunakan rumus, hal ini berpengaruh pada kesimpulan jawaban yang dilakukan siswa, kesalahan kategori kesimpulan hilang banyak terjadi di soal Nomor 3 karena ada beberapa siswa yang hanya mengerjakan sampai tahap menemukan nilai Un sehingga siswa melakukan kesalahan kategori oc yaitu tidak sampai pada kesimpulan akhir yang diminta pada soal, karena pada soal tersebut meminta siswa untuk menemukan nilai dari Sn bukan nilai Un.

\section{Soal Nomor 4}

Kesalahan siswa dalam menjawab soal Nomor 1 berdasarkan kategori Watson kemudian dianalisis dan dituangkan kedalam tabel 4:

Tabel 4. Hasil analisis soal Nomor 4

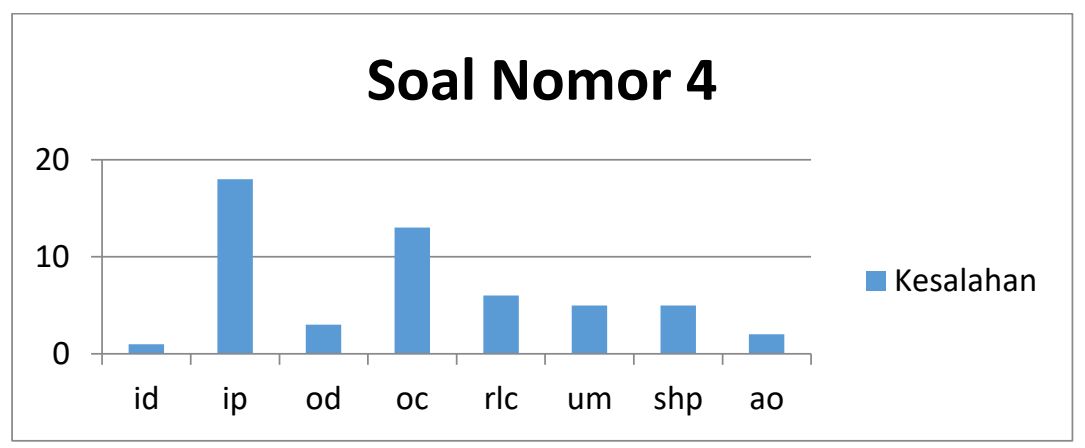

Analisis Soal:

Berdasarkan Tabel 4 masih terdapat siwa yang melakukan kesalahan, yang paling menonjol yaitu tipe prosedur tidak tepat dan tipe kesimpulan hilang. Sebagian besar siswa sudah sampai menemukan nilai dari $r$ tetapi berhenti karena tidak mengetahui prosedur 
selanjutnya yang harus dilakukan dalam menjawab soal yang diberikan. Sehingga siswa masih terlihat belum memahami materi pada soal ini. Karena siswa tidak dapat melakukan prosedur dengan tepat maka siswa juga banyak melakukan kesalahan tipe oc yaitu kesimpulan hilang, siswa belum sampai pada tahap akhir yang diminta pada soal karena siswa juga tidak melakukan prosedur dengan tepat yaitu tidak mengetahui tahap yang akan dilakukan selanjutnya, yang terakhir terdapat 2 siswa yang tidak mengerjakan soal.

\section{Persentase Jenis Kesalahan}

Berdasarkan Tabel 5 untuk soal Nomor 1 terlihat bahwa kesalahan ip dan $o c$ merupakan kesalahan paling banyak dilakukan oleh siswa masing-masing sebesar 30\% dan $21,67 \%$. Siswa masih salah dalam menentukan rumus dan masih banyak siswa yang belum paham, sehingga kesalahan oc juga terjadi karena pada awalnya siswa tidak mengetahui rumus apa yang harus digunakan maka siswa juga tidak sampai pada tahap menyimpulkan.

Berdasarkan Tabel 5 untuk soal Nomor 2 kesalahan terbanyak dilakukan oleh siswa adalah tipe Ip dan $u m$. Pada kesalahan manipulasi tidak langsung siswa masih salah dalam merubah dari tahap yang satu ke tahap selanjutnya yaitu sebesar 33,3\%, penyebab dari kesalahan tersebut karena siswa masih bingung dalam melakukan manipulasi karena kurang latihan dalam mengerjakan soal matematika.

Berdasarkan Tabel 5 untuk soal Nomor 3 tentang jumlah suku ke n siswa masih banyak melakukan kesalahan tipe ip yaitu prosedur tidak tepat sebesar 29,63\% disebabkan karena siswa masih salah dalam melakukan langkah-langkah penyelesaian yang tepat, dan kedua adalah kesalahan oc dimana $24,52 \%$ siswa belum sampai pada tahap akhir yang diminta pada soal meskipun langkah awal yang digunakan sudah benar tetapi ada siswa berhenti saat menyelesaikan soal diantaranya karena siswa lupa dengan rumus, lupa dengan langkah yang akan dilakukan selanjutnya, dan karena siswa kekurangan waktu dalam menjawab.

Berdasarkan Tabel 5 untuk soal Nomor 4 juga terdapat kesalahan yang sama seperti soal-soal lainnya yaitu kesalahan pada kategori ip sebanyak 33,96\% hal ini menunjukan bahwa siswa belum bisa memahami materi pada soal tersebut, karena siswa belum memahami materi maka siswa salah dalam prosedur yang digunakan yang mengakibatkan kesalahan tipe $o c$ yaitu kesimpulan hilang juga terjadi kesalahan sama besarnya dilakukan oleh siswa yaitu $26,4 \%$, karena siswa tidak mampu menyelesaikan jawaban yang diminta pada soal.

\section{Pembahasan}


Solusi yang dapat diberikan untuk mengurangi kesalahan pada kategori posedur tidak tepat adalah siswa diberikan LKS dengan jawaban terbimbing dan tidak terbimbing secara rutin oleh guru, maksudnya adalah pada saat memulai pembelajaran atau pada saat pembelajaran telah selesai dilakukan maka, guru memberikan LKS dengan dua tipe jawaban yaitu tipe jawaban terbimbing dan tipe jawaban tidak terbimbing dengan tipe soal yang sama. Guru juga dapat memberikan tugas rumah siswa dengan tipe LKS seperti tersebut.

Hal ini bisa melatih siswa untuk memahami materi barisan dan deret, bisa mengingat tahap-tahap yang harus dilakukan agar tidak lupa, dan siswa lebih terbiasa dalam menyelesaikan soal matematika dengan sabar dan teliti, yang kedua adalah pada saat pembelajaran di kelas, guru memberikan perhatian lebih kepada siswa yang masih salah dalam menyelesaikan soal, yaitu membimbing siswa tersebut dalam mengerjakan soal latihan maupun saat pembelajaran berlangsung, memberikan kesempatan siswa tersebut untuk bertanya, dan menjawab soal dipapan tulis dengan dibimbing oleh guru maupun teman lainnya, dan solusi yang ketiga adalah mengadakan evaluasi evaluasi pembelajaran,yaitu sebelum melanjutkan kemateri baru guru memperhatikan siswa yang belum menguasai materi yang sudah diberikan, jika siswa belum paham materi tersebut jangan langsung loncat ke materi selanjutnya karena ketidaktahuan siswa akan semakin menumpuk, bisa diadakan pembelajaran yang berbeda dari sebelumnya misalnya diadakan pembelajaran kelompok, dalam setiap kelompok terdapat siswa yang berkemampuan tinggi, sedang, dan rendah. Masing-masing anak saling mengajarkan materi maupun latihan-latihan soal kepada temannya yang belum paham, setelah itu setiap siswa dalam kelompok diberikan soal untuk dikerjakan dan dalam setiap kelompok tersebut akan mendapatkan nilai yang sama yaitu diambil dari teman kelompok yang mendapatkan nilai terkecil. Sehingga setiap anak dalam kelompok akan saling mengajarkan temannya agar bisa, dan teman lainnya juga mau belajar bersungguh-sungguh.

\section{KESIMPULAN}

Kesalahan yang sering dilakukan oleh siswa adalah kategori prosedur tidak tepat, kesalahan tersebut disebabkan karena siswa lupa rumus, belum paham pada materi barisan dan deret dengan besar persentase 34,06\%, dengan kesalahan kategori tersebut mengakibatkan siswa salah dalam menentukan penyelesaian.

\section{UCAPAN TERIMAKASIH}


Penulis mengucapkan terima kasih kepada keluarga yang telah memberikan dorongan, doa, serta suportnya, kepada Ibu Anggita Maharani dan Ika Wahyuni yang telah banyak membantu dalam karya tulis ini.

\section{DAFTAR PUSTAKA}

Hastari, C. H. (2018). Analisis Kesulitan Penyelesaian Soal Matematika Ditinjau dari Kecerdasan Emosional Mahasiswa di Kabupaten Tulungagung. JNPM (Jurnal Nasional Pendidikan Matematika), Vol. 2 No. 2, Hal. 180-196

Huljannah, M. (2015). Analisis Kesalahan Siswa dalam Menyelesaikan Soal Persamaan dan Identitas Trigonometri Berdasarkan Kategori Watson di Kelas X SMA Al-Azhar Palu. Aksioma (Jurnal Pendidikan Matematika), Vol. 4, No.2

Hariyani, S., Aisyah, F. N. K., \& Dinullah, R. N. I. (2019). Analisis Kesalahan Penyelesaian Soal Cerita Berdasarkan Kriteria Watson. Jurnal Review Pembelajaran Matematika, Vol 4, No 1, Hal 11-22.

Isran, I. (2017). Analisis Kesalahan Siswa Dalam Menyelesaikan Tes Kemampuan Berpikir Kritis Materi Fungsieksponen Dengan Panduan Kriteria Watson. Kontinu: Jurnal Penelitian Didaktik Matematika, Vol 1, No 1.

Maharani, A. (2014). Psikologi Pembelajaran Matematika di SMK untuk Mendukung Implementasi Kurikulum 2013. Jurnal Euclid, Vol. 1, No. 2, Hal 60-136

Manullang, S., dkk. (2017). Matematika SMA/MA/SMK/MAK Kelas XI. Kemendikbud: Jakarta

Munawaroh, N., Rohaeti, E. E., \& Aripin, U. (2018). Analisis Kesalahan Siswa Berdasarkan Kategori Kesalahan Menurut Watson dalam Menyelesaikan Soal Komunikasi Matematis Siwa SMP. JPMI (Jurnal Pembelajaran Matematika Inovatif), Vol 1, No 5, hal 993-1004.

Madalińska-Michalak, J., \& Bavli, B. (2018). Challenges in teaching English as a foreign language at schools in Poland and Turkey. European Journal of Teacher Education, 41(5), 688-706.

Nurhikmah, S \& Febrian. (2016). Analisis Kesalahan Siswa dalam Menyelesaikan Permasalahan Integral Tak Tentu. Jurnal Pemikiran dan Penelitian Pendidikan. Vol. 14, No. 2

Ratnasari, Y., Rosita, C. D., Pramuditya, S. A. (2017). Pengaruh Model Pembelajaran Reciprocal Teaching Terhadap Kemampuan Pemahaman dan Komunikasi Matematis Siswa. Jurnal Procediamath. Vol. 1

Sudirman. (2016). Analisis Kecenderungan Kesalahan Mahasiswa Dalam Menyelesaikan Soal Materi Segitiga. Gema wiralodra, Vol 7, No 1, Hal 179-187 
Susilawati, S., \& Febrian, F. (2016). Analisis Kesalahan Siswa Kelas X Mia 3 SMA Negeri 1 Tanjungpinang Tahun Pelajaran 2015/2016 Dalam Menyelesaikan Permasalahan Peluang Dengan Menggunakan Kategori Kesalahan Watson. Jurnal Pendidikan Matematika, Vol 10, No 2, Hal 39-52. 